\title{
BACTERIOCIN PRODUCTION BY LACTOBACILLUS PENTOSUS ST712BZ ISOLATED FROM BOZA
}

\author{
Svetoslav D. Todorov; Leon M.T. Dicks* \\ Department of Microbiology, University of Stellenbosch, 7600 Stellenbosch, South Africa \\ Submitted: September 23, 2005; Returned to authors for corrections: August 10, 2006; Approved: November 15, 2006
}

\begin{abstract}
Bacteriocin ST712BZ (14.0kDa in size) inhibits the growth of Lactobacillus casei, Escherichia coli, Pseudomonas aeruginosa, Enterococcus faecalis, Klebsiella pneumoniae and Lactobacillus curvatus. Growth of strain ST712BZ in BHI, M17, soy milk and molasses was similar to growth in MRS, with optimal bacteriocin production $(12800 \mathrm{AU} / \mathrm{mL})$ recorded in MRS after $24 \mathrm{~h}$. The same level of bacteriocin production (12800AU/mL) was recorded in MRS broth with an initial pH of 6.5, 6.0 and 5.5. However, MRS broth (pH 6.5) supplemented with $1 \mathrm{mM}$ EDTA, yielded only $6400 \mathrm{AU} / \mathrm{mL}$. Low levels of bacteriocin activity were recorded in MRS broth with an initial $\mathrm{pH}$ of 5.0 and 4.5. Of all media compositions tested, MRS supplemented with tryptone $(20.0 \mathrm{~g} / \mathrm{L})$, glucose $(20.0$ to $40.0 \mathrm{~g} / \mathrm{L})$, mannose $(20.0 \mathrm{~g} / \mathrm{L})$, vitamin $\mathrm{B}_{12}$, or vitamin C yielded $12800 \mathrm{AU} /$ $\mathrm{mL}$. Glycerol concentrations of $1.0 \mathrm{~g} / \mathrm{L}$ and higher repressed bacteriocin production. Maximal bacteriocin activity (25600AU/mL) was recorded in MRS supplemented with Vit. B ${ }_{1}$ or DL-6,8-thioctic acid.
\end{abstract}

Key words: Bacteriocin ST712BZ; Lactobacillus pentosus; boza

\section{INTRODUCTION}

Cereals are fermented in most regions of the world and a variety of raw materials and fermentation conditions are used, mostly with lactic acid bacteria and yeast as starter cultures. Lactic acid bacteria play an important role in the preservation, microbiological stability and production of aroma compounds in these products (27).

A few papers have been published on the microbial composition of boza, a beverage traditionally produced in Bulgaria and prepared from a combination of different cereals $(14,12,3,35)$. Most of the lactic acid bacteria that have been isolated from boza belong to the genera Lactobacillus spp., Lactococcus spp. and Leuconostoc spp. and as many as 33 strains revealed antibacterial activity against a number of Gram-positive bacteria, including Listeria innocua, and a few Gram-negative bacteria, including Escherichia coli (14). In most of these studies, the antimicrobial properties of the strains have been ascribed to the production of bacteriocins $(27,33)$, defined as small proteins or peptides with bactericidal or bacteriostatic activity against genetically closely related species (17).

Few bacteriocin-producing strains of Lactobacillus pentosus have been reported, namely bacteriocins produced by strains 191 and 204, isolated from sucuk (8); bacteriocins ST151BR and ST112BR produced by strains ST151BR and ST112BR, respectively $(29,30)$; a bacteriocin produced by a commercial starter culture (25); and pentocin TV35b, produced by strain TV $35 b$ isolated from vaginal secretions (26).

In recent papers $(20,23)$, specific environmental conditions, including those found in food, have been studied to determine their effect on the production of bacteriocins. Bacteriocin production changes dramatically upon altering of environmental conditions and optimum production may require a specific combination of environmental parameters (19). Little is known about the interactions these factors have on the production of a bacteriocin, especially in a complex food environment.

Two papers have reported on the effect of nitrogen and carbon in the medium on the production of bacteriocins ST151BR and ST112BR produced by L. pentosus $(29,30)$.

*Corresponding Author. Mailing address: Departament of Microbiology - JC Smuts Building, block A - Corner of De Beers And Merriman Avenue University of Stellenbosch - Stellenbosch 7600 - South Africa. Tel.: (2721) 808-5850 ou (2721) 808-5846. E-mail: 1mtd@sun.ac.za 
Studies on bacteriocins from other lactic acid bacteria, e.g. pediocin PD-1 (24), enterocin AS-48 (2), enterocin P (13), sakacinP (1), bacteriocins produced by L. mesenteroides L124 (21), plantaricin ST31 (31) and plantaricin UG1 (11) have suggested that production is often regulated by growth $\mathrm{pH}$ and temperature. In some cases, higher bacteriocin activity has been recorded at sub-optimal growth conditions $(22,5,18,1,31)$.

The aim of this study was to determine the conditions needed for optimal production of bacteriocin ST712BZ produced by $L$. pentosus ST712BZ isolated from boza.

\section{MATERIALS AND METHODS}

\section{Bacterial strains and growth conditions}

Strain ST712BZ, isolated from boza, was classified as $L$. pentosus based on phenotypic and genotypic characteristics (33). The strain was cultured in MRS medium (Biolab, Biolab Diagnostics, Midrand, SA) at $30^{\circ} \mathrm{C}$ and stored at $-80^{\circ} \mathrm{C}$ in spent MRS broth, supplemented with 15\% (v/v) glycerol. MRS broth (Biolab) was used in all experiments, except growth optimization, in which case MRS broth (10) was modified as indicated.

\section{Bacteriocin bioassay}

Bacteriocin screening was performed by using the agarspot-test method (32). Correction of the cell-free supernatant to $\mathrm{pH} 6.0$ with $1 \mathrm{M} \mathrm{NaOH}$ prevented the inhibitory effect of lactic acid. Antimicrobial activity was expressed as arbitrary units (AU/mL), calculated as $a^{b} \times 100$, where "a" represents the dilution factor and "b" the last dilution that produces an inhibition zone of at least $2 \mathrm{~mm}$ in diameter. Activity is expressed per $\mathrm{mL}$ by multiplication with 100 . One AU is defined as the reciprocal of the highest dilution showing a clear zone of growth inhibition (32). Lactobacillus casei LHS was used as indicator strain.

\section{Molecular size of the bacteriocins}

L. pentosus ST712BZ was cultured in MRS broth (Biolab) for $20 \mathrm{~h}$ at $30^{\circ} \mathrm{C}$. The cells were harvested $\left(8000 \mathrm{xg}, 10 \mathrm{~min}, 4^{\circ} \mathrm{C}\right)$ and the bacteriocins precipitated from the cell-free supernatants with $60 \%$ saturated ammonium sulphate. The precipitate was re-suspended in one tenth volume $25 \mathrm{mM}$ ammonium acetate ( $\mathrm{pH}$ 6.5), desalted against distilled water by using a 1000Da cutoff dialysis membrane (Spectrum Inc., CA, USA) and then separated by tricine-SDS-PAGE, as described by Schägger and Von Jagow (28). A low molecular-weight marker with sizes ranging from 2.5 to $45.0 \mathrm{kDa}$ (Amersham International) was used. The gels were fixed and one half overlaid with $L$. casei LHS $\left(10^{6} \mathrm{CFU} / \mathrm{mL}\right)$, embedded in Brain Heart Infusion (BHI) agar (Biolab) to determine the position of the active bacteriocin, as described by Todorov and Dicks (29).

\section{Bacteriocin production in different growth media and at different initial growth $\mathrm{pH}$}

An 18h-old culture of strain ST712BZ was inoculated (2\%, v/v) into MRS broth (Biolab), BHI broth, M17 broth (Merck), soy milk $(10 \%, \mathrm{w} / \mathrm{v}$, soy flour) and molasses $(10 \%, \mathrm{w} / \mathrm{v})$, respectively. Incubation was at $30^{\circ} \mathrm{C}$ and $37^{\circ} \mathrm{C}$, respectively, without agitation, for $25 \mathrm{~h}$. Samples were taken every hour and examined for bacterial growth (OD at $600 \mathrm{~nm})$, changes in culture $\mathrm{pH}$, and production of bacteriocins $(\mathrm{AU} / \mathrm{mL})$. The agar-spottest method was used, with $L$. casei LHS as target organism.

In a separate experiment, the effect of initial medium $\mathrm{pH}$ on the production of bacteriocin ST712BZ was determined. Volumes of $300 \mathrm{~mL}$ MRS broth were adjusted to $\mathrm{pH} 4.5,5.0$, $5.5,6.0$ and 6.5 , respectively, with $6 \mathrm{M} \mathrm{HCl}$ or $6 \mathrm{M} \mathrm{NaOH}$ and then autoclaved. Each flask was inoculated with $2 \%(\mathrm{v} / \mathrm{v})$ of an $18 \mathrm{~h}$-old culture of $L$. pentosus ST712BZ and incubated at $30^{\circ} \mathrm{C}$ for $24 \mathrm{~h}$, without agitation. Changes in culture $\mathrm{pH}$ and production of bacteriocin ST712BZ, expressed as AU/mL, were determined every hour as described elsewhere. All experiments were done in triplicate.

\section{Effect of medium composition on bacteriocin production}

L. pentosus ST712BZ was grown in $10 \mathrm{~mL}$ MRS broth (Biolab) for $18 \mathrm{~h}$ at $30^{\circ} \mathrm{C}$, the cells harvested by centrifugation $(8000 \mathrm{xg}$, $10 \mathrm{~min}, 4^{\circ} \mathrm{C}$ ), and the pellet re-suspended in $10 \mathrm{~mL}$ sterile peptone water. Four $\mathrm{ml}$ of the cell suspension was used to inoculate 200 $\mathrm{mL}$ of the following media: (a) MRS broth (10), without organic nutrients, supplemented with tryptone $(20.0 \mathrm{~g} / \mathrm{L})$, meat extract $(20.0 \mathrm{~g} / \mathrm{L})$, yeast extract $(20.0 \mathrm{~g} / \mathrm{L})$, tryptone $(12.5 \mathrm{~g} / \mathrm{L})$ plus meat extract $(7.5 \mathrm{~g} / \mathrm{L})$, tryptone $(12.5 \mathrm{~g} / \mathrm{L})$ plus yeast extract $(7.5 \mathrm{~g} / \mathrm{L})$, meat extract $(10.0 \mathrm{~g} / \mathrm{L})$ plus yeast extract $(10.0 \mathrm{~g} / \mathrm{L})$, or a combination of tryptone $(10.0 \mathrm{~g} / \mathrm{L})$, meat extract $(5.0 \mathrm{~g} / \mathrm{L})$ and yeast extract $(5.0 \mathrm{~g} / \mathrm{L})$, respectively; (b) MRS broth, i.e. with $20.0 \mathrm{~g} / \mathrm{L}$ D-glucose; (c) MRS broth without D-glucose, supplemented with $20.0 \mathrm{~g} / \mathrm{L}$ fructose, sucrose, lactose, mannose, and maltose, respectively; (d) MRS broth with 1.0 to $40.0 \mathrm{~g} / \mathrm{L}$ glucose as sole carbon source; (e) MRS broth with 2.0 to 100.0 $\mathrm{g} / \mathrm{L} \mathrm{K}_{2} \mathrm{HPO}_{4}$; and (f) MRS broth supplemented with 1.0 to 50.0 $\mathrm{g} / \mathrm{L}$ glycerol.

In a separate experiment, the vitamins cyanocobalamin (Sigma, St. Louis, Mo.), L-ascorbic acid (BDH Chemicals Ltd), thiamine (Sigma) and DL-6,8-thioctic acid (Sigma) were filtersterilised and added to MRS broth at $1.0 \mathrm{mg} / \mathrm{mL}$ (final concentration). All cultures were incubated at $30^{\circ} \mathrm{C}$ for $24 \mathrm{~h}$. Activity levels of bacteriocin ST712BZ were determined as described elsewhere. All experiments were done in triplicate.

\section{Plasmid isolation}

Plasmid DNA was isolated according to the method described by Burger and Dicks (6), followed by $\mathrm{CsCl}$ density gradient centrifugation (4). The DNA was separated on an agarose gel, according to Ausubel et al. (4). 


\section{RESULTS AND DISCUSSION}

All data represent an average of three repeats. The values recorded in each experiment did not vary by more than $5 \%$ and single data points are presented in the figures without standard deviation bars.

The cell-free supernatant of $L$. pentosus ST712BZ inhibited the growth of L. casei, E. coli, Pseudomonas aeruginosa, Enterococcus faecalis, Klebsiella pneumoniae and Lactobacillus curvatus (33). According to tricine-SDS-PAGE, bacteriocin ST712BZ is approximately $14.0 \mathrm{kDa}$ (Fig. 1). No plasmid DNA was isolated.

Growth of $L$. pentosus ST712BZ in BHI, M17, soy milk and molasses was very similar to growth in MRS (Fig. 2). The cell density of both strains increased from $\mathrm{OD}_{600 \mathrm{~nm}} 0.02$ to approximately 9.0 (dilution factor taken into calculation) during 25h (Fig. 2). Low levels of bacteriocin ST712BZ activity (less than $200 \mathrm{AU} / \mathrm{mL}$ ) were detected after $6 \mathrm{~h}$ of growth in MRS broth

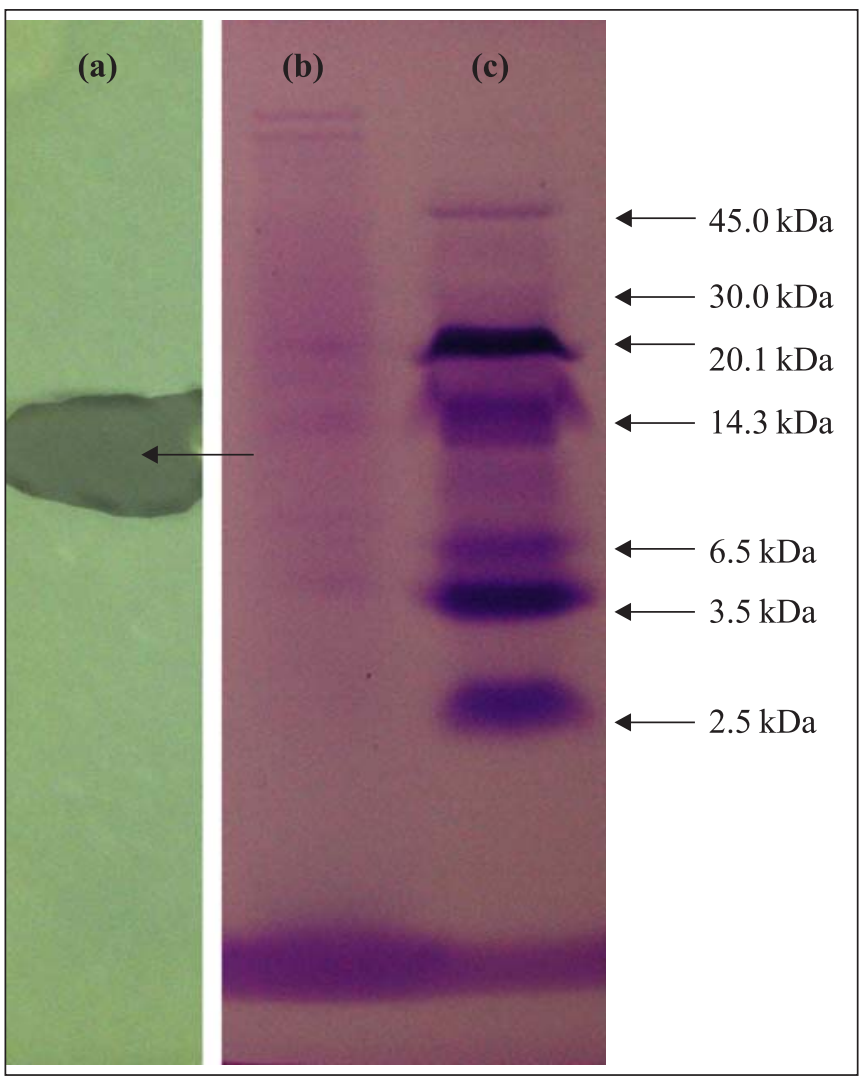

Figure 1. Tricine-SDS-PAGE of bacteriocin ST712BZ. Lane (a): Zone of growth inhibition, corresponding to the position of the bacteriocin band. Lane (b): Peptide band stained with Coomassie Blue R250. Lane (c): Molecular weight marker. The gel was covered with viable cells of $L$. casei LHS (approximately $10^{6}$ $\mathrm{CFU} / \mathrm{mL}$ ), imbedded in BHI agar. Incubation was at $30^{\circ} \mathrm{C}$ for $24 \mathrm{~h}$.

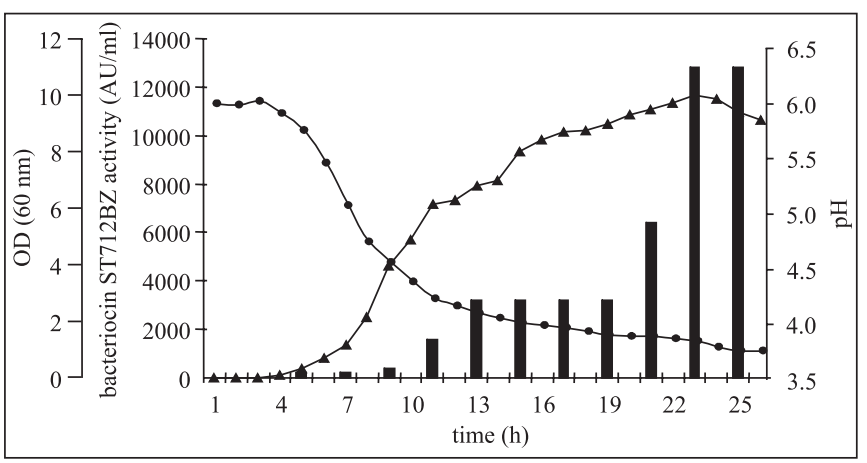

Figure 2. Growth of strain ST712BZ ( - $\boldsymbol{\Delta}$ - ), production of bacteriocin ST712BZ ( - bars - ) and changes in $\mathrm{pH}$ ( - - ) in MRS broth (Biolab).

(Fig. 2). Optimal production of bacteriocin ST712BZ (12800AU/ $\mathrm{mL}$ ) was recorded after $24 \mathrm{~h}$ (Fig. 2), and only when incubated at $30^{\circ} \mathrm{C}$. Only $6400 \mathrm{AU} / \mathrm{mL}$ for ST712BZ was recorded when the cells were incubated at $37^{\circ} \mathrm{C}$ (not shown). Bacteriocin ST712BZ is a primary metabolite. Similar results have been reported for bacteriocin ST151BR (29), plantaricin Y (7) and bacteriocins produced by $P$. acidilactici (25).

The activity of bacteriocin ST712BZ did not decrease during $72 \mathrm{~h}$ of incubation at $25^{\circ} \mathrm{C}$, suggesting that extracellular proteases have not been produced. Optimal bacteriocin production $(12800 \mathrm{AU} / \mathrm{mL})$ was recorded in MRS broth with an initial $\mathrm{pH}$ of 6.5, 6.0 and 5.5 (Table 1). In MRS broth (pH 6.5) supplemented with $1 \mathrm{mM}$ EDTA, bacteriocin ST712BZ production was $6400 \mathrm{AU} / \mathrm{mL}$. Low levels of bacteriocin activity were recorded when the strains were cultured in MRS broth with an initial $\mathrm{pH}$ of 5.0 and 4.5 (Table 1). The culture $\mathrm{pH}$ after $24 \mathrm{~h}$ growth was between 3.52 and 3.75. Similar results have been reported for other bacteriocins produced by L. pentosus $(29,30)$ and L. plantarum $(9,15,31)$.

Table 1. Influence of initial medium $\mathrm{pH}$ on production of bacteriocin ST712BZ in MRS broth (Biolab).

\begin{tabular}{lccccc}
\hline & \multicolumn{5}{c}{ Initial $\mathrm{pH}$} \\
\cline { 2 - 6 } & 4.5 & 5.0 & 5.5 & 6.0 & 6.5 \\
\hline Final pH & 3.5 & 3.6 & 3.7 & 3.7 & 3.8 \\
$\Delta \mathrm{pH}$ & 1.0 & 1.4 & 1.9 & 2.3 & 2.8 \\
Bacteriocin activity (AU/mL) & 3200 & 6400 & 12800 & 12800 & 12800 \\
OD $_{600 \mathrm{~nm}}$ & 8.3 & 8.8 & 9.2 & 9.1 & 9.4 \\
$\begin{array}{l}\text { Specific bacteriocin activity } \\
\text { (AU/mL/OD }\end{array}$ 600nm) & 386 & 727 & 1391 & 1407 & 1362 \\
$\begin{array}{l}\text { Changes in bacteriocin } \\
\text { activity (\%)* }\end{array}$ & 25 & 50 & 100 & 100 & 100 \\
\hline
\end{tabular}

*Compared to 12 800AU/mL recorded in MRS broth (Biolab). 
Growth of strain ST712BZ in BHI broth or M17 broth adjusted to $\mathrm{pH} 6.5$ yielded only $400 \mathrm{AU} / \mathrm{mL}$ of bacteriocin ST712BZ (Table $2)$. No bacteriocin production was recorded in $10 \%(\mathrm{w} / \mathrm{v})$ soy milk (Table 2). Low levels of bacteriocin ST712BZ (200AU/mL) were recorded when the strains were grown in $10 \%(\mathrm{w} / \mathrm{v})$ molasses (Table 2). Specific nutrients are required for the production of the bacteriocin ST712BZ. This phenomenon has been observed for other bacteriocins, e.g. bacteriocins ST151BR and ST112BR $(29,30)$.

Tryptone $(20 \mathrm{~g} / \mathrm{L})$, or a combination of tryptone and yeast extract (1:0.6), added to basal MRS medium yielded a bacteriocin level of $12800 \mathrm{AU} / \mathrm{mL}$ (Table 2). Growth in the presence of a combination of tryptone and meat extract (1:0.6) reduced bacteriocin production with 50\%. Growth in the presence of

Table 2. Influence of organic nitrogen, carbohydrates, growth medium and potassium on the production of bacteriocin ST712BZ

\begin{tabular}{|c|c|c|c|c|}
\hline \multirow[b]{2}{*}{ Component } & \multirow[b]{2}{*}{$\begin{array}{c}\text { Concentration } \\
(\mathrm{g} / \mathrm{L})\end{array}$} & \multirow[b]{2}{*}{$\mathrm{pH}$} & \multicolumn{2}{|c|}{ Bacteriocin ST712BZ } \\
\hline & & & $\begin{array}{l}\text { Activity } \\
\text { (AU/mL) }\end{array}$ & $\begin{array}{c}\text { Changes in bacteriocin } \\
\text { activity }(\%)^{*}\end{array}$ \\
\hline Tryptone & 20.0 & 3.8 & 1280 & 100 \\
\hline Meat extract & 20.0 & 3.7 & 1600 & 13 \\
\hline Yeast extract & 20.0 & 3.7 & 3200 & 25 \\
\hline Tryptone + meat extract & $12.5+7.5$ & 3.7 & 6400 & 50 \\
\hline Tryptone + yeast extract & $12.5+7.5$ & 3.7 & 12800 & 100 \\
\hline Meat extract + yeast extract & $10.0+10.0$ & 3.8 & 3200 & 25 \\
\hline Tryptone + meat extract + yeast extract & $10.0+5.0+5.0$ & 3.8 & 12800 & 100 \\
\hline Glucose & 20.0 & 3.7 & 12800 & 100 \\
\hline Fructose & 20.0 & 4.0 & 1600 & 13 \\
\hline Sucrose & 20.0 & 3.8 & 6400 & 50 \\
\hline Maltose & 20.0 & 3.8 & 3200 & 25 \\
\hline Mannose & 20.0 & 3.7 & 12800 & 100 \\
\hline Lactose & 20.0 & 4.0 & 3200 & 25 \\
\hline Gluconate & 20.0 & 5.2 & 3200 & 25 \\
\hline \multirow[t]{6}{*}{ Glycerol } & 0 & 3.8 & 12800 & 100 \\
\hline & 1.0 & 3.8 & 6400 & 50 \\
\hline & 5.0 & 3.8 & 6400 & 50 \\
\hline & 10.0 & 3.8 & 6400 & 50 \\
\hline & 20.0 & 3.8 & 3200 & 25 \\
\hline & 50.0 & 3.8 & 3200 & 25 \\
\hline MRS & 50.0 & 3.8 & 12800 & 100 \\
\hline BHI & 37.0 & 6.1 & 400 & 3 \\
\hline M17 & 42.5 & 6.0 & 400 & 3 \\
\hline Soy flour & 100.0 & 4.3 & 0 & 0 \\
\hline Molasses & 100.0 & 4.1 & 200 & 2 \\
\hline $\mathrm{K}_{2} \mathrm{HPO}_{4}$ & 2.0 & 3.8 & 12800 & 100 \\
\hline \multirow[t]{2}{*}{$\mathrm{KH}_{2} \mathrm{PO}_{4}$} & 2.0 & 3.8 & 12800 & 100 \\
\hline & $(\mathrm{mg} / \mathrm{mL})$ & & & \\
\hline Cyanocobalamin (Vit. $B_{12}$ ) & 1.0 & 4.0 & 12800 & 100 \\
\hline Thiamine (Vit. $\left.\mathrm{B}_{1}\right)$ & 1.0 & 4.0 & 25600 & 200 \\
\hline DL-6,8-thioctic acid & 1.0 & 4.0 & 25600 & 200 \\
\hline L-ascorbic acid (Vit. C) & 1.0 & 4.0 & 12800 & 100 \\
\hline Control & 0 & 3.9 & 12800 & 100 \\
\hline
\end{tabular}

*Compared to $12800 \mathrm{AU} / \mathrm{mL}$ recorded in MRS broth (Biolab). 
either yeast extract, or a combination of meat extract and yeast extract (1:1), resulted in bacteriocin production of 3200AU/mL (Table 2). Growth in the presence of only meat extract yielded only $1600 \mathrm{AU} / \mathrm{mL}$.

Tryptone is the key nitrogen source needed for optimal production of bacteriocin ST712BZ. Similar results have been reported for the production of plantaricin 423 (34) and for bacteriocins ST151BR and ST112BR $(29,30)$. In the case of plantaricin 423, optimal bacteriocin production was recorded in MRS broth supplemented with bacteriological peptone, followed by casamino acids, tryptone and meat extract. Stimulation of bacteriocin production by yeast extract and meat extract has been reported for helveticin J (16). As far as we could determine, this is the first indication that tryptone is the key nitrogen source needed in the production of $L$. pentosus bacteriocins.

Growth of strain ST712BZ in the presence of glucose (20.0, 30.0 and $40.0 \mathrm{~g} / \mathrm{L}$ ) yielded $12800 \mathrm{AU} / \mathrm{mL}$ of bacteriocin ST712BZ (Fig. 3A). Lower concentrations of glucose $(1.0 \mathrm{~g} / \mathrm{L}, 5.0 \mathrm{~g} / \mathrm{L}$ and $10.0 \mathrm{~g} / \mathrm{L}$ ) yielded $800 \mathrm{AU} / \mathrm{mL}, 800 \mathrm{AU} / \mathrm{mL}$ and $6400 \mathrm{AU} / \mathrm{mL}$, respectively (Fig. 3A). Growth in presence of mannose (20 g/L) yielded the same activity as $20 \mathrm{~g} / \mathrm{L}$ glucose (Table 2). Growth in the presence of sucrose $(20.0 \mathrm{~g} / \mathrm{L})$ reduced bacteriocin

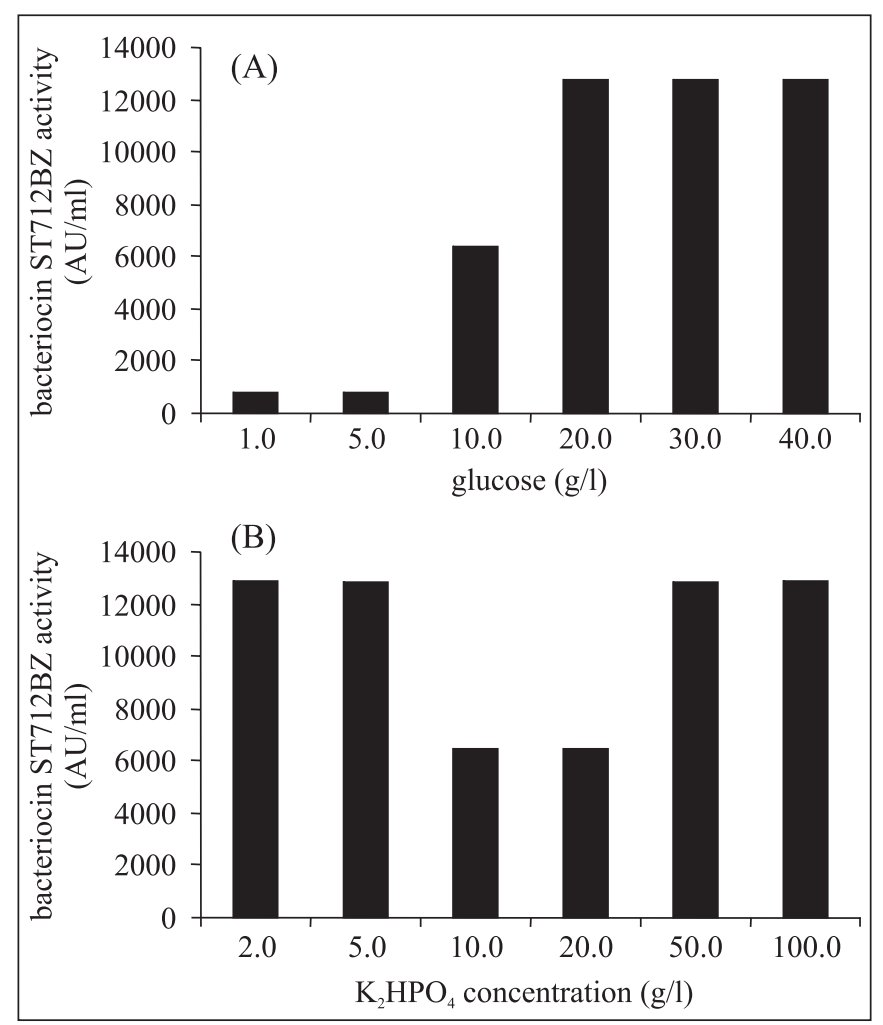

Figure 3. Effect of glucose (A) and $\mathrm{K}_{2} \mathrm{HPO}_{4}$ (B) on the production of bacteriocin ST712BZ. production by $50 \%$, i.e to $6400 \mathrm{AU} / \mathrm{mL}$. Gluconate, maltose and lactose $(20.0 \mathrm{~g} / \mathrm{L})$, on the other hand, yielded $3200 \mathrm{AU} / \mathrm{mL}$ (Table 2). Low activity $(1600 \mathrm{AU} / \mathrm{mL})$ was recorded in the presence of $20.0 \mathrm{~g} / \mathrm{L}$ fructose. Based on these results, the production of bacteriocin ST712BZ is stimulated when cells are grown in medium supplemented with 20.0 to $40.0 \mathrm{~g} / \mathrm{L}$ glucose.

Bacteriocin ST712BZ production remained at 12800AU/ $\mathrm{mL}$ when strain ST712BZ was grown in the presence of $\mathrm{K}_{2} \mathrm{HPO}_{4}$ or $\mathrm{KH}_{2} \mathrm{PO}_{4}$ (Fig. 3B). Growth in the presence of $10.0 \mathrm{~g} / \mathrm{L}$ or 20.0 $\mathrm{g} / \mathrm{L}$ yielded $6400 \mathrm{AU} / \mathrm{mL}$ bacteriocin ST712BZ (Fig. 3B). In the case of plantaricin $\mathrm{UG} 1,7.0 \mathrm{~g} / \mathrm{L} \mathrm{K} \mathrm{HPO}_{4}$ resulted in increased activity (11). Concentrations of 10.0 and $20.0 \mathrm{~g} / \mathrm{L} \mathrm{K}_{2} \mathrm{HPO}_{4}$ lowered bacteriocin ST151BR activity by $50 \%$ (29). In the case of bacteriocin ST112BR, higher levels of activity were recorded when the medium contained $5.0 \mathrm{~g} / \mathrm{L}, 10.0 \mathrm{~g} / \mathrm{L}$ and $20.0 \mathrm{~g} / \mathrm{L}$ $\mathrm{KH}_{2} \mathrm{PO}_{4}(30)$. The optimal concentration of $\mathrm{K}_{2} \mathrm{HPO}_{4}$ required for plantaricin ST31 production was between $2.0 \mathrm{~g} / \mathrm{L}$ and 5.0 $\mathrm{g} / \mathrm{L}(31)$.

Production of bacteriocin ST712BZ was the highest (12800AU/mL) in the absence of glycerol (Table 2). Glycerol concentrations of $1.0 \mathrm{~g} / \mathrm{L}$ and higher (up to $50.0 \mathrm{~g} / \mathrm{L}$ ) led to decreased levels of bacteriocin ST712BZ production (Table 2). Similar results were reported for the production of bacteriocins ST151BR, ST112BR and plantaricin ST31 (29,30,31). An increase in glycerol leads to a lowering in water activity. The production of bacteriocin ST712BZ may be influenced by osmotic stress.

Bacteriocin ST712BZ production of $12800 \mathrm{AU} / \mathrm{mL}$ was recorded in the presence or absence of Vit. $\mathrm{B}_{12}$ or Vit. C (Table 2). A increase in production levels was recorded in MRS supplemented with Vit. $B_{1}$ or DL-6,8-thioctic acid up to $25600 \mathrm{AU} /$ $\mathrm{mL}$ (Table 2). In the case of bateriocin ST151BR, produced by $L$. pentosus ST151BR, the latter vitamins had no effect on production levels (29). However, these vitamins led to a 50\% decrease in the production of bacteriocin ST112BR, produced by L. pentosus ST112BR (30).

\section{ACKNOWLEDGMENTS}

This research was funded by National Research Foundation (NRF) South Africa.

\section{RESUMO}

\section{Bacteriocina produzida por Lactobacillus pentosus ST712BZ isolad de boza}

A bacteriocina ST712BZ produzida par Lactobacillus pentosus (peso molecular de 14,0kDa) inibe o crescimento de Lactobacillus casei, Escherichia coli, Pseudomonas aeruginosa, Enterococcus faecalis, Klebsiella pneumoniae e Lactobacillus curvatus. O crescimento de L. pentosus ST712BZ 
em BHI, M17, leite de soja e melaços foi semelhante ao observado em MRS, registando-se a produção máxima de bacteriocina (12800UA/mL) em MRS após 24 h. Observou-se o mesmo nível de produção de bacteriocina $(12800 \mathrm{UA} / \mathrm{mL}) \mathrm{em}$ caldo MRS com pH inicial de 6,5, 6,0 e 5,5. No entanto, em caldo MRS (pH 6,5) suplementado com 1 mM de EDTA a produção apenas atingiu $6400 \mathrm{UA} / \mathrm{mL}$. Os níveis de atividade bacteriocinogênica detectados em caldo MRS com um pH inicial de 5,0 e 4,5 foram baixos. De todas as fórmulas de meios de cultura testadas a que apresentou a atividade máxima 12800UA/ $\mathrm{mL}$ foi MRS suplemento de triptona $(20,0 \mathrm{~g} / \mathrm{L})$, glicose $(20,0 \mathrm{e}$ 40,0 g/L), manose $(20.0 \mathrm{~g} / \mathrm{L})$, vitamina $\mathrm{B}_{12}$ e vitamina C. A produção de bacteriocinas foi inibida por concentrações de glicerol superiores ou iguais a $1.0 \mathrm{~g} / \mathrm{L}$. Verificou-se a actividade bacteriocinogênica máxima (25600UA/mL) em caldo MRS suplementado com vitamina $B_{1}$ ou ácido DL-6,8-thioctic.

Palavras-chave: Bacteriocina ST712BZ, Lactobacillus pentosus, boza

\section{REFERENCES}

1. Aasen, I.M.; Moreto, T.; Katla, T.; Axelsson, L.; Storro, I. (2000). Influence of complex nutrients, temperature and $\mathrm{pH}$ on bacteriocin production by Lactobacillus sakei CCUG 42687. Appl. Microbiol. Biotechnol., 53:159-166.

2. Abriouel, H.; Valdivia, E.; Galvez, A.; Maqueda, M. (2001). Influence of physico-chemical factors on the oligomerization and biological activity of bacteriocin AS-48. Curr. Microbiol., 42:89-95.

3. Arici, M.; Daglioglu, O. (2002). Boza: A lactic acid fermented cereal beverage as a traditional Turkish food. Food Rev. Int., 18:39-48.

4. Ausubel, F.M.; Brent, R.; Kingston, R.E.; Moore, D.D.; Seidman, J.G.; Smith, J.A.; Struhl, K. (1994). Current protocols in molecular biology, John Wiley and Sons, Inc, New York.

5. Bogovic-Matijasic, B.; Rogelj, I. (1998). Bacteriocin complex of Lactobacillus acidophilus LF221 - production studies in MRS-media at different $\mathrm{pH}$-values and effect against Lactobacillus helveticus ATCC 15009. Process Biochem., 33: 345-352.

6. Burger, J.H.; Dicks, L.M.T. (1994). Technique for isolating plasmids from exopolysaccharide producing Lactobacillus spp. Biotech. Techniq., 8: 769-772.

7. Chin, H.S.; Chin, J.S.; Kim, J.M.; Yang, R.; Yoon, S.-S. (2001). Detection and antibacterial activity of a bacteriocin produced by Lactobacillus plantarum. Food Sci. Biotech., 10: 335-341.

8. Çon, A.H.; Gökalp, H.Y. (2000). Production of bacteriocin-like metabolites by lactic acid cultures isolated from sucuk samples. Meat Sci., 55: 89-96.

9. Daeschel, M.A.; McKeney, M.C.; McDonald, L.C. (1990). Bacteriocidal activity of Lactobacillus plantarum C-11. Food Microbiol., 7: 91-98.

10. De Man, J.C.; Rogosa, M.; Sharpe, M.E. (1960). A medium for the cultivation of lactobacilli. J. Appl. Bacteriol., 23: 130-135.

11. Enan, G.; Essawy, A.A.; Uyttendaele, M.; Debevere, J. (1996). Antibacterial activity of Lactobacillus plantarum UG1 isolated from dry sausage: Characterization, production and bactericidal action of plantaricin UG1. Int. J. Food Microbiol., 30: 189-215.

12. Gotcheva, V.; Pandiella, S.S.; Angelov, A.; Roshkova, Z.G.; Webb, C. (2000). Microflora identification of the Bulgarian cereal-based fermented beverage boza. Process Biochem., 36: 127-130.
13. Herranz, C.; Martinez, J.M.; Rodriguez, J.M.; Hernandez, P.E.; Cintas, L.M. (2001). Optimization of enterocin P production by batch fermentation of Enterococcus faecium $\mathrm{P} 13$ at constant pH. Appl. Microbiol. Biotechnol., 56: 378-383.

14. Ivanova, I.; Kabadjova, P.; Pantev, A.; Danova, S.; Dousset, X. (2000). Detection, purification and partial characterization of a novel bacteriocin substance produced by Lactococcus lactis susp lactis B14 isolated from boza - Bulgarian traditional cereal beverage. Vestnik Moskovskova Universiteta Kimia, 41: 47-53.

15. Jimenez-Diaz R.; Rios-Sanchez R.M.; Desmazeaud M.; Ruiz-Barrba J.L.; Piard J.-C. (1993). Plantaricin S and T, two new bactericins produced by Lactobacillus plantarum LPCO10 isolated from a green olive fermentation. Appl. Environ. Microbiol., 59: 1416-1424.

16. Joerger, M.C.; Klaenhammer, T.R. (1986). Characterization and purification of helveticin $\mathrm{J}$ and evidence for chromosomally determined bacteriocin produced by Lactobacillus helveticus 481 . J. Bacteriol., 167: 439-446.

17. Klaenhammer, T. (1988). Bacteriocins of lactic acid bacteria. Biochemistry, 70: 337-349.

18. Krier, F.; Revol-Junelles, A.M.; Germain, P. (1998). Influence of temperature and $\mathrm{pH}$ on production of two bacteriocins by Leuconostoc mesenteroides subsp. mesenteroides FR52 during batch fermentation. Appl. Microbiol. Biotechnol., 50: 359-363.

19. Leal-Sánchez, M.V.; Jiménez-Díaz, R.; Maldonado-Barragán, A.; Garrido-Fernández, A.; Ruiz-Barba, J.L. (2002). Optimization of bacteriocin production by batch fermentation of Lactobacillus plantarum LPCO10. Appl. Environ. Microbiol., 68: 4465-4471.

20. Leroy, F.; De Vuyst, L. (2003). A combined model to predict the functionality of the bacteriocin-producing Lactobacillus sakei strain CTC494, Appl. Environ. Microbiol., 69: 1093-1099.

21. Mataragas, M.; Metaxopoulos, J.; Galiotou, M.; Drosinos, E.H (2003). Influence of $\mathrm{pH}$ and temperature on growth and bacteriocin production by Leuconostoc mesenteroides L124 and Lactobacillus curvatus L442. Meat Sci., 64: 265-271.

22. Matsusaki, H.; Endo, N.; Sonomoto, K.; Ishizaki A. (1996). Lantibiotic nisin $\mathrm{Z}$ fermentative production by Lactococcus lactis IO-1: Relationship between production of the lantibiotic and lactate and cell growth. Appl. Microbiol. Biotechnol., 45: 36-40.

23. Motta, A.S.; Brandelli, A. (2003). Influence of growth conditions on bacteriocin production by Brevibacterium linens. Appl. Microbiol. Biotechnol., 62: 163-167.

24. Nel, H.A.; Bauer, R.; Vandamme, E.J.; Dicks, L.M.T. (2001). Growth optimisation of Pediococcus damnosus NCFB 1832 and the influence of $\mathrm{pH}$ and nutrients on the production of pediocin PD-1. J. Appl. Microbiol., 91:1131-1138.

25. Nieto-Lozano, J.C.; Reguera-Useros, J.I.; Pelaez-Martinez, M.C.; De la Torre, A.H. (2002). Bacteriocinogenic activity from starter cultures used in Spanish meat industry. Meat Sci., 62: 237-243.

26. Okkers, D.J.; Dicks, L.M.T.; Silvester, M.; Joubert, J.J.; Odendaal, H.J. (1999). Characterization of pediocin TV35b, a bacteriocin-like peptide isolated from Lactobacillus pentosus with a fungistatic effect on Candida albicans. J. Appl. Microbiol., 87: 726-734.

27. Requena, T.; Pelàez, C. (1995). Actividad antimicrobiana de bacterias lacticas. Produccion de bacteriocinas, Rev. Espan. Cienc. Tecnol. Aliment., 35:19-44.

28. Schägger, H.; Von Jagow, G. (1987). Tricine-sodium dodecyl sulphatepolyacrylamide gel electrophoresis for the separation of proteins in the range from 1 to $100 \mathrm{kDa}$. Anal. Biochem., 166: 368-379.

29. Todorov, S.D.; Dicks, L.M.T. (2004). Effect of medium components on bacteriocin production by Lactobacillus pentosus ST151BR, a strain isolated from beer produced by the fermentation of maize, barley and soy flour. World J. Microbiol. Biotechnol., 20: 643-650.

30. Todorov, S.D.; Dicks, L.M.T. (2004). Influence of growth medium on bacteriocin production by Lactobacillus pentosus ST112BR, a strain isolated from traditional South African beer. Proceedings of 
National conference with foreign participation, 3-4 Juny, 2004, Stara Zagora, Bulgaria. Volume IV, Human medicine. Part 1. Clinical and molecular biology, microbiology. Physiology and pharmacology. Publishing group: Stara Zagora Union of Scientists, 132-136.

31. Todorov, S.; Gotcheva, B.; Dousset, X.; Onno, B.; Ivanova, I. (2000). Influence of growth medium on bacteriocin production in Lactobacillus plantarum ST31. Biotechnol. Biotechnol. Eq., 14: 50-55

32. Todorov S.D.; Dicks, L.M.T. (2005). Lactobacillus plantarum isolated from molasses produces bacteriocins active against Gramnegative bacteria. Enzyme Microb. Technol., 36: 318-326.
33. Todorov, S.D.; Dicks, L.M.T. (2006). Screening for bacteriocinproducing lactic acid bacteria from boza, a traditional cereal beverage from Bulgaria. Comparison of the bacteriocins. Process Biochem., 41: 11-19.

34. Verellen, T.L.J.; Bruggeman, G.; Van Reenen, C.A.; Dicks, L.M.T.; Vandamme, E.J. (1998). Fermentation optimisation of plantaricin 423, a bacteriocin produced by Lactobacillus plantarum 423. J. Ferment. Bioeng., 86: 174-179.

35. Zorba, M.; Hancioglu, O.; Genc, M.; Karapinar, M.; Ova, G. (2003) The use of starter cultures in the fermentation of boza, a traditional Turkish beverage. Process Biochem., 38: 1405-1411. 